\title{
ERCP with stenting of traumatic pancreatic duct transection: A case report
}

\author{
Deepa Prashant Makhija, M.Ch., Jayesh Desale, M.Ch., Charu Tiwari, M.Ch., Hemanshi Shah, M.Ch.
}

Department of Paediatric Surgery, T.N.M.C, Mumbai-India

\begin{abstract}
Pancreatic injuries, though rare, are associated with high morbidity because of location of pancreas adjacent to the various hollow and solid organs. Difficulty in early diagnosis adds to morbidity. Condition of the pancreatic duct is an important factor in grading the injury and deciding upon course of management. Conservative management is the line of treatment in lower grade injuries. Higher grades of pancreatic injuries are usually managed surgically. Endoscopic retrograde cholangiopancreaticography (ERCP) has recently emerged as an effective diagnostic as well as therapeutic modality for hepatobiliary and pancreatic pathologies. Presently described is case of a I2-year-old boy who presented with post-traumatic complete transection of pancreatic duct, which was successfully managed by ERCP-guided stenting of the duct. Therapeutic advantages of ERCP in trauma setting and difficulties involved are highlighted.
\end{abstract}

Key words: Blunt abdominal trauma; ERCP; pancreatic transection; stenting.

\section{INTRODUCTION}

Blunt abdominal trauma is principal cause of abdominal injury in children. In absence of hemodynamic instability, unresponsiveness to resuscitation, or associated hollow visceral injuries, non-operative management of blunt abdominal trauma is well documented and widely accepted. However, the same cannot be said for blunt injuries involving the pancreas, as there is still much debate about optimal management.

Pancreatic injury is uncommon and occurs in $3 \%$ to $12 \%$ of blunt abdominal trauma. ${ }^{[1]}$ However, in addition to pancreatic parenchymal injury, due to close proximity of adjacent solid and hollow organs and vascular structures, pancreatic injury is associated with high morbidity rate of up to $60 \%$ and high mortality rate of up to $30 \% .^{[2]}$

In order to reduce the serious consequences caused by pancreatic injury, an accurate and early diagnosis of pancreatic

Address for correspondence: Hemanshi Shah, M.D.
A L Nair Road, Mumbai Central, Mumbai, 40008 Maharashtra, India.
$\begin{array}{ll}\text { Tel: +022-2302767। } & \text { E-mail: hemanshisshah@gmail.com } \\ \text { Qucik Response Code } & \text { Ulus Travma Acil Cerrahi Derg } \\ & \text { 2016;22(6):566-568 } \\ & \text { doi: } 10.5505 / \text { tjtes.2016.09334 } \\ & \text { Copyright 2016 }\end{array}$

injury is of utmost importance. However, pancreatic injury lacks early clinical signs due to retroperitoneal location of the pancreas. Also, since biochemical tests such as serum amylase levels can be unreliable, it is often very difficult to diagnose pancreatic injury at an early stage. Endoscopic retrograde cholangiopancreatography (ERCP) is the gold standard for ductal evaluation. ${ }^{[3]}$ ERCP has also shown promising results as minimally invasive therapeutic alternative. Condition of the pancreatic duct is not only an important factor for evaluation of severity of pancreatic injury, but also an important basis for choice of therapy. Although early and precise evaluation of the pancreatic duct is crucial, ERCP has been underutilized because of perceived difficulty in performing the procedure and a lack of available expertise. ${ }^{[2]}$

Presently described is a case of traumatic pancreatic duct transection managed with endoscopic stent placement.

\section{CASE REPORT}

A 12-year-old boy was referred from peripheral hospital with suspected pancreatic injury on computed tomography (CT) scan. There was history of fall from ladder I day earlier with blunt abdominal trauma. On examination, patient had tachycardia and was normotensive. There was tenderness and guarding in the upper abdomen. On investigation, there was moderately elevated serum amylase (336 IU/L). CT of abdomen was suggestive of suspected breach in the pancreatic 
neck and hypodense non-enhancing peripancreatic collection with moderate free fluid (Fig. Ia). There was no evidence of any other solid organ injury. Magnetic resonance cholangiopancreaticography (MRCP) showed near complete transection at the junction of head and neck of the pancreas, $9 \times 5 \times 6$
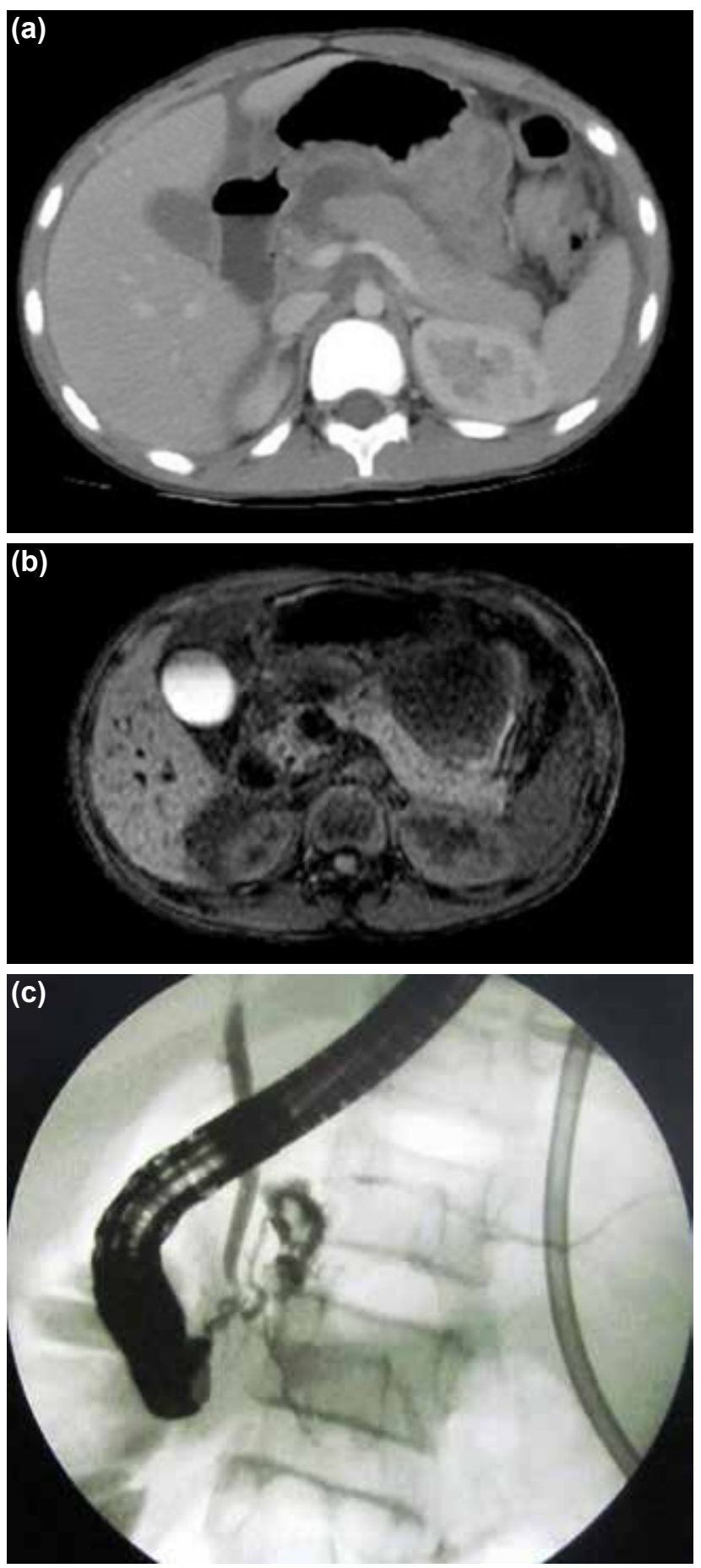

Figure 1. (a) Computed tomography of abdomen suggesting suspected breach in the pancreatic neck and hypodense nonenhancing peripancreatic collection. (b) Magnetic resonance cholangiopancreaticography showing near complete transection at the head-neck junction of the pancreas and normal distal main pancreatic duct. (c) Endoscopic retrograde cholangiopancreatography revealing leak at the genu. $\mathrm{cm}$ collection in the lesser sac, and distal main pancreatic duct was normal (Fig. Ib). Ultrasonography-guided external drainage of peripancreatic collection was performed. ERCP was done on day 7 of trauma, which revealed leak at the genu (Fig. Ic). Stenting of the pancreatic duct was completed using $5 \mathrm{~F}$ stent. Patient's serum amylase showed decreasing trend. Oral diet was initiated. External drain output progressively decreased. After confirming absence of collection on ultrasound, drain was removed. ERCP with stent removal was performed at 6 weeks. Patient was doing well on follow-up.

\section{DISCUSSION}

As retroperitoneal location offers relative protection, injury to the pancreas is unusual in blunt abdominal trauma; occurrence of high-grade or ductal injury is rare, with an estimated frequency of $0.12 \%{ }^{[4]}$ Most common etiology is bicycle handle bar injury. ${ }^{[5]}$ Diagnosis involves high index of suspicion, as symptoms are often insidious in onset and serum enzyme markers (amylase and lipase) usually do not correlate with severity of injury and may be normal in proportion of injuries. [6] Early diagnosis is crucial in pancreatic injury, and while CT and MRCP are good, non-invasive imaging modalities, ERCP has been proven to be the most specific and sensitive diagnostic tool. ${ }^{[6]}$ Management of pancreatic injury is based on 2 factors: integrity of the main pancreatic duct and location of the pancreatic injury, both of which constitute the American Association for the Surgery of Trauma grading system. ${ }^{[6]}$

Evolution in management of blunt pancreatic injuries over the last 20 years has trended toward non-operative management of lower grade injuries, with surgical intervention reserved for high grade injuries. ${ }^{[6]}$ Decision to pursue conservative treatment rather than operative intervention depends on hemodynamic stability of the patient, whether injury is isolated, and suitability of injury for endoscopic treatment. ${ }^{[6]}$ Current literature is divided on the benefits of operative intervention, with outcome measures focused on length of hospital stay, failure of non-operative management, need for repeat intervention, and rates of surgical complications. ${ }^{[6]}$ There are no consensus guidelines, but non-operative management is usually advocated in the first instance.

Simple external drainage is frequently proposed as standard surgical procedure for treating contusions or small lacerations. Cited rationale is removal of activated proteolytic enzymes that can lead to formation of fistulae, abscesses, and pseudocysts. ${ }^{[4]}$

Potential advantages of ERCP as an adjunct to non-operative management may include reduced rates of pseudocyst formation, shorter hospital stay, and quicker return to oral intake. Common potential risks of non-operative management are pancreatic duct strictures, atrophy of the distal duct despite intervention, post-ERCP pancreatitis, and need for future intervention. ERCP and the expertise needed to perform this 
procedure in pediatric population may not be readily available and can limit utilization of ERCP at smaller centers. ${ }^{[7]}$

Most of previously reported studies are from small case series with retrospective data, and literature for the pediatric population is even more sparse. However, ERCP has been recommended for consideration in all children with blunt abdominal trauma since as early as 1986. ERCP for diagnosis, definitive therapy, or as an adjuvant to avoid laparotomy may be beneficial in some cases and should be considered for evaluation of higher grade pancreatic injuries.

\section{Conclusion}

Pancreatic injury in blunt abdominal trauma in adolescent patients is infrequent and often difficult to diagnose. This case emphasizes need for clinical suspicion based on mechanism of injury, even in a relatively innocuous fall from a ladder. When pancreatic injury is identified, method of management is determined by condition of the patient, severity of injury, and anatomical location. Adequate external drainage is an important principle in management of pancreatic injuries. There is still controversy regarding optimal management of pancreatic injury involving ducts. No absolute algorithm can be used to treat these patients. Suspected ductal injuries can be effectively managed endoscopically and such injuries should promptly be referred to a specialist center for appropriate and timely management.

\section{Conflict of interest: None declared.}

\section{REFERENCES}

1. Potoka DA, Gaines BA, Leppäniemi A, Peitzman AB. Management of blunt pancreatic trauma: what's new? Eur J Trauma Emerg Surg 2015;41:239-50. Crossref

2. Yalin K, Xiaojun H, Chengli L, Gang Z, Mei X, Yuying Z, et al. Gradingtherapeutic strategy for pancreatic injury after blunt abdominal trauma: therapy based on the condition of pancreatic duct and report of 95 cases. Hepatogastroenterology 2013;60:1497-503.

3. Ito Y, Kenmochi T, Irino T, Egawa T, Hayashi S, Nagashima A, et al. Endoscopic management of pancreatic duct injury by endoscopic stent placement: a case report and literature review. World J Emerg Surg 2012;7:21. Crossref

4. Maeda K, Ono S, Baba K, Kawahara I. Management of blunt pancreatic trauma in children. Pediatr Surg Int 2013;29:1019-22. Crossref

5. Lam JP, Eunson GJ, Munro FD, Orr JD. Delayed presentation of handlebar injuries in children. BMJ 2001;322:1288-9. Crossref

6. Zala A, Gaszynski R, Punch G. Blunt trauma pancreatic duct injury managed by non-operative technique, a case study and literature review. Trauma Case Reports 1 2015;13-6. Crossref

7. Garvey EM, Haakinson DJ, McOmber M, Notrica DM. Role of ERCP in pediatric blunt abdominal trauma: a case series at a level one pediatric trauma center. J Pediatr Surg 2015;50:335-8. Crossref

\title{
OLGU SUNUMU - ÖZET
}

\author{
Travmatik pankreas kanal transeksiyonunda stentlemeyle birlikte ERKP: Olgu sunumu \\ Dr. Deepa Prashant Makhija, Dr. Jayesh Desale, Dr. Charu Tiwari, Dr. Hemanshi Shah \\ Pediyatrik Cerrahi Anabilim Dalı, T.N.M.C, Mumbai-Hindistan
}

Seyrek görülmekle birlikte pankreas yaralanmaları çeşitli içi boş ve solid organlara yakınlıkları nedeniyle yüksek bir morbiditeyle ilişkilidir. Erken tanı koyma zorluğu morbiditeye katkıda bulunmaktadır. Pankreas kanalının durumu yaralanmayı derecelendirmede ve tedavi kararında önemli bir etkendir. Düşük dereceli yaralanmalarda konservatif tedavi uygulanır. Daha yüksek dereceli pankreas yaralanmaları genellikle cerrahi yolla tedavi edilir. Son zamanlarda kolanjiyobiliyer ve pankreatik patolojilerin etkili tanısal ve terapötik bir yöntemi olarak endoskopik retrograd kolanjiyopankreatikografi (ERKP) kullanılmaya başlanmıştır. Bu yazıda, endoskopik retrograd kolanjiyopankreatikografi kılavuzluğunda pankreas kanalı stentlenerek başarılı bir şekilde tedavi edilen posttravmatik komplet pankreas kanal transeksiyonu olan I 2 yaşındaki bir erkek çocuğu sunuldu. Travma ortamında ERKP'nin terapötik avantajları ve ilişkin zorluklar vurgulanmaktadır.

Anahtar sözcükler: ERKP; künt karın travması; pankreas transeksiyonu; stentleme.

Ulus Travma Acil Cerrahi Derg 2016;22(6):566-568 doi: 10.5505/tjtes.2016.09334 